\title{
Søgaard omkring Aar 1800.
}

\author{
Af P. H. Moos, Sognepræst i Kliplev.
}

Ved Landevejen mellem Aabenraa og Flensborg ligger Godset Søgaard i henrivende Omgivelser ved skovomkranset Sø. Beundres Gaarden for sin skønne Beliggenhed, interesserer den ikke mindre ved sine historiske Minder.

Gaarden ligger i Kliplev Sogn, Hovedbyen i Lundtoft Herred, der tidligere hed Kliplev Herred. De gamle Forhold mindes endnu ved "Thingstien", der kan efterspores fra Felsted til Kliplev, hvor altsaa Thinget $i$ sin Tid er holdt. I Kapellerne til Kliplev Kirke findes Lig af ca. 30 Ahlefeldter fra Sogaard. I Kirken findes en Herskabsstol, "Søgaards Loft«, med Ahlefeldternes Vaaben.

Søgaard er sandsynligvis bygget af Slægten Limbæk i Grev Gerts Dage, men inden Aar 1400 er den kommen i Ahlefeldternes Eje, og disse beholdt den til 1725, da de gik Fallit og maatte trække sig tilbage til Langeland.

Det, vi nu kalder Søgaard, er kun Avlsgaarden, selve Slottet laa paa en "Pold « i Søen, en Bro fo:bandt den med Land baade mod Syd og Nord.

Landevejens Anlæg $18 \mathrm{~A} 7$ har ganske forandret Forholdene; Ingeniørerne skyede ingen Vanskeligheder. Nordfor Gaarden lagde de Vejen gennem de høje Bjergskov Bakker. Søgaard Sø gik dc tværs over og 
lagde ogsaa Vejen over en Del af Slotsgrunden. Endnu ser vi en Del af Borgpladsen estfor Vejen. Selve Slottet var bleven odelagt af Torstenson og hans Svenskere i November 1643. Det opbyggedes ikke mere, Herskabet flyttede til Graasten Slot, der oprindelig var rejst som et Jagtslot for Herrerne paa Søgaard.

Sagaards Beliggenhed var oprindelig meget afsides. Hovedfærdselsaaren var Hærvejen, nu kaldet Oxevejen, 1 Mil længere mod Vest.

Hvordan selve Gaarden er opstaaet, vides ikke. Det sædvanlige, at en Herregaard opstaar, ved at et Par Bol blev slaaet sammen, forklarer ikke Sagen her, da Sogaards oprindelig hjemlige Areal har været ca. 3500 Tdr. Land. Ler er intet, der tyder paa, at de har nedlagt Landsbyer for at skabe en Avlsgaard ved Søgaard Slot. Mod Nord fik Byen Bjergskov Lov til at ligge i Fred, 6 ringe Gaarde, sat i Skat som "Kaadnere«, de 5 laa ved Hostrup Sø, den sjette Øst for "Bjergene«. Mod Syd ligger "Lyngtoft", nu Lundtoft, uberørt. Kliplev Bønders Jorder dækkedes af Søgaard Skov. Men længere borte ejede Søgaard store Gaarde; ved Fallitauktionen 1725 frasolgtes: Graasten, Fiskbæk, Kiding, Grøngrøft, Aarup, Ballegaard, Skobølgaard, Bøjskov, Kjelstrup, Kværs Ladegaard og Stoltelund (Tinglev Sogn). Desuden var Bønderne $i$ en vid Omegn Fæstere og maatte svare Afgifter og gare Hoverianbejde t:1 Søgaards og de andre Herregaardes Drift.

Ved Auktionen $1725 \mathrm{kom}$ selve Sogaard og Aartoft i den tyske Landraad von Thienens Eje. Aartoft har optaget en lille Herregaard, Fruermark, i Tiden 1650 -1700. Den nye Slægt ejede Sugaard 1725-1834. De 
boede der ikke, lod Avlingen bestyre eller bortforpagtede den, Af Forpagtere nævner vi: Den bekendte Patriot fra Flensborg Frans Bøckmann fra 1739 til sin Død 1741; det er hans Enke, Else Helene, f. Turnier, der har skænket den smukke Klingpung til Kliplev Kirke. 1804-17 var Nis Jakobsen Forpagter, han er Stamfader til den bekendte Skærbækpræst, samt til flere Gaardmandsslægter her paa Egnen. Slægten von Thienen var lidet livskraftig. Godske v. T. dør 1744 ugift; hans Brodersøn, Hieronymus v. T. dør 1786 ligeledes ugift; dennes Halvbroder Werner von d. Schulenburg dør 1810 som den sidste af Slægten. Leopold Wilhelm v. d. Schulenburg hørte til en sidelinje; han solgte Sogaard 1834. Sagnet ved intet ondt at fortælle om disse Ejere. Køberen var en Advoikat fra Slesvig, G. F. Güntzel, død 1844; hans Hustru, f. Dreyer, havde Gaarden til sin Død 1852. De beboede Sogaard. Eftertiden ved lidet godt at fortælle om dem; deres uanselige Grav findes ved Sydsiden af Klipiev Kirke.

I Bondefrigørelsens Dage besluttede Werner v. d. Schulenburg at sælge $\in \mathrm{n}$ Del af Grodset ved Auktion den 1. August $1791 \mathrm{og}$ følgende Dage. Auktionsconditionerne blev trykte, og Exemplarer af dem opberares endnu paa Gaarde her paa Egnen.

Aartoft skulde udparcellercs. Stamparcellen skulde være (118 Tdr. Land, 3 store Parceller var pa: 139, 182 og $196 \mathrm{Tdr}$, men der blev kun solgt Jord t:1 en Gaard og nogle Smaasteder, deriblandt Lille Aartoft med Krohold ved Aabenraa-Kliplev gamle Landevej. Hovedparcellen købtes af Rasmus Petersen fra Varnæs, men Slægten holdt sig kun til 1812 pa: denne uhaandterlige magre Gaard. 
Bedre gik det med Salg af Jord fra Søgaard; 1500 Tdr. Land var udlagt i XIX Parceller, de fleste mod Nord for Gaarden, Sønderkobbel sydfor Søen.

Opmaalingen var foretaget af Landmaaler Niels Jepsen fra Felsted. Til hver Parcel blev henlagt Ager og Eng, Mose eller Skov, saa de ikke skal savne Bræultsel. Desulen fik de 3 a (; Fag Hus, som de kunde nedbryde paa Sogaard, nemlig af Svinestalden, den store og den lille Kostald, den store Lade og $\gg$ Buttermühlenhaus". Efter Sigende sad der i Parcellisternes forste Bygninger Mursten fra den gamle Slotsruin, men om de selv har brudt dem ud af Murene, eller Herremanden havde anvendt dem i de Avlsbygninger, som de fik Lov til at tage, vides ikke.

Der sikredes hver Parcellist 1 Mands- og 1 Kvindeplads i Kliplev Kirke og ligeledes Gravplads paa den trange Kirkegaard, der laa omkring Kirken. Godsejeren var jo Kirkepatron og kunde saaledes sikre dem mod de gamle Beboeres Vrede, naar de kom i Kirke, eller naar de forlangte Gravplads til deres Dode.

Skovparcellerne udlagdes for det meste paa Bjergskov Bakker, men Træbestanden maa have varet meget ringe; f. Ex. Parcel XI, i Gejlkobbel (ved det senere Søgaards Bomhus) fik 1 Td. 3 Skp. Skov $\mathbf{i}$ Bjergskov; Trabestanden taxeres til at vare 61 Favne til en Værdi af 120 Rigsdaler, 24 skilling, som Koberen maa betale foruden Jorden. Denne gamle Lovskov huskes ikke mere, ingen ved her at fortælle om, naar og hvorledes den er forsvunden. I en Beskrivelse fra 1827 hedder det, at Skoven er borte for flere Aar siden. I Froslev ved de at fortælle, at da de en Morgen efter en Stormnat sua over mod Bjergskov, var 
Skoven forsvunden. En senere Ejer, Amtmand Helzen anlagde en Granplantage paa $80 \mathrm{Td}$. Land, den blev omhugget og solgt under Verdenskrigen, men endnu vokser noget Krat af Lovtræer paa Bakkerne og minder om den gamle Løvskov. Selv uden Skov ejer Bjergskov Bakker stor Naturskønhed, nogle af dem er nylig blevet fredede. Udsigten over Hostrup sio og Egnen til alle Sider er storslaaet, men ogsaa ved Udsigten her mindes man om, at en stor Del af Sogaard Herregaardsmarker nu afgiver $\mathrm{Hjem}$ for en fri Landbobefolkning.

Gaardene blev solgt som Arvefaste, egentlig fri Ejendom, kun skulde de svare en Afgift ved Ejerskifte. Købesummen blev mindre byrdefuld, ved at de skulde svare en aarlig Pengeafgift, Canon; den var noget forskellig, 28, 32, 40 Skilling pr. Td. Land. En lille Parcel paa $8 \mathrm{Tdr}$. Land ved Vejen fra Kversballe til Søgaard var passende til en Kro, og maatte derfor give en Rigsdaler pr. Td. Land i Canon.

Denne aarlige Afgift gav Anledning til idelige /Forsøg paa at opnaa Nedsættelse; den foltes i Længden som en Uret og blev i Prøjsertiden afløst sammer med andre Realbyrder.

Søgaard havde Kliplev Kirkes Kapital til Laans; nu fik Parcellisterne disse Penge at forrente til Kirken. Takket være den tyske Valutapolitik har de nu efter Krigen kunnet betale Laanet tilbage i vardilose tyske Sedler.

Køberne var mest østfra; Felsted, Kværs, Adsbøl Sogne var deres Hjemsted; et Par kom ude fra Sofiendal Koloniby i Tinglev Sogn.

Fra 1. Maj 1792 kunde. de tiltræde deres nye Ejendomme, men allerede i Efteraaret 1791 kunde de be- 
gynde at dyrke Jorden; fra sugaard fik de sæderug og Hjælp til Bearbejdelsen. Fra Herremandens Side faar man Indtryk af en human Bestræbelse for at gare det saa let for Parcellisterne som mulig; det var jo ogsaa i Tidens Aand i Bondefrigorelsens Dage. Nu maatte Koberne tage fat at skabe sig Hjem paa de gamle Herregaardsmarker, Krat og Sten maatte ryddes bort, Jorden maatte udgrøftes osv., men navnlig den østlige Del, Bremsmaj og omliggende, viste sig at være fortrinlig, svær Jord. Bygningerne har vist været tarvelige, de er forlsengst ombyggede. Det var frie Bønder, der nu arbejdede paa egen Jord uden Hoveri eller anden Afhængighed af Herremanden, blot de svarede deres Pengeafgifter. En Del Gaarde er blevne i Slægten, paa flere sidder nu det \&. Slægtled under langt bedre Kaar end dem, der begyndte derude paa de ode Marker.

Parcellisternes Born blev henviste til at soge Bjergskov Skole. Denne holdtes oprindelig i en Stue i en lille Hytte i Bjergskov, men Skolen flyttedes senere nærmere til søgaard; nu er den en statelig Bygning nordfor Søgaard, men paa Grund af sin Oprindelse kaldes den stadig Bjergskov Skole, skønt den ligger langt inde paa Søgaard's Grund. - Lykken har ikke været med Herregaarden siden de Dage. Vi har en Beskrivelse af Søgaard fra 1823. Da holdtes der 12 Heste, hvoraf 2 var en Snes Aar gamle, der var 13 Køer, røde, rodbrogede, sorte, graa, 7 Faar og 1 Ged. Paa Gaarden var der 3 Mergelkærrer, tohjulede Vogne, hvor Vognkassen sad i Hængsler, saa den kunde slaas bag over, og Merglen afvæltes paa en Gang. Man kan deraf se, at Merglingen var il Gang her paa. Egnen. Dernæst fandtes en Stenkærre til at bortslæbe 
Sten med af Markerne. 1 gammel Gouningsslæde er sagtens bleven brugt om Vinteren til at føre Godningen ud paa Marken. 3 Jernplove, 3 Jernharver, 3 Jernharver med Træpigge, 1 ny Harve til at slaa sammen, fortæller vel om Fremskridt fra Træredskabernes Tid, men med de 3 Plove skulde de ikke komme vidt paa de store Marker. I sin Dagligstue havde Forpagteren (i betrukne Stole, 1 Bord med Klapper og 1 Jernovn. Borgestuen indeholdt 1 Seng, saa Vxrelset var baade Spisestue, Opholdsvarelse for Folkene om Dagen og Sovevarelse formodentlig for Pigerne; dernæst fandtes der 1 nyt Bord med 2 Bænke, 2 gamle Stole, en Lerovn, formodentlig opmuret af Teglsten, 1 sort Stykke Voxdug, saa Folkene ikke skulde savne den Hygge at have "Dug« paa Bordet.

Da Güntzel blev Ejer og tog Bolig paa Gaarden, var det 200 Aar siden en Ejer havde boet paa Sogaard. Han ombyggede Stuehuset, anlagde Haven, forte en ny Kirkevej til Kliplev gennem Skoven; han købte en Del af den i 1791 solgte l'arceljord tilbage, saa to af Parcelgaardene nedlagdes. Gaarden kom i bedre Drift end for.

Men at de store Landbrugs Tid er forbi, kendes deraf, at $\mathrm{i}$ vor 'Tid, 1922, solgtes ca. $430 \mathrm{Tdr}$. Land fra Søgaard, saa der til selve Sogaarú blev af Ager, Skov, Sø, Eng og Mose 900 Hectarer tilpage.

Tiderne skifter. Søgaard beboeies en Gang af Herrer, som til deres Underhold havde Jord vidt omkring og havde Bønderne til at give sig Afgifter og Hoveriarbejde; Historien fortaller mere om, hvordan den enkelte Familie paa slottet havde det, end hvordan de Hundreder af Familier i Bondergaarde og 
Huse befandt sig, de var til, for at man kunde leve godt paa slottet.

$\mathrm{Nu}$ ser vi efter, om del kan skabes de flest mulige lykkelige Hjem; alle er lige, Herremand, Gaardmænd og Husmænd; og den Tankegang passer bedst med Kristendommen. 